\title{
Pembelajaran Menulis Puisi di Sekolah Menengah Atas
}

\author{
Sutikno $^{\mathrm{a} 1}$, Retno Winarni ${ }^{\mathrm{a}, 2}$, Suyitno ${ }^{\mathrm{a}, 3}$, dan Nugraheni Eko Wardani ${ }^{\mathrm{a}, 4}$ \\ ${ }^{\text {a } U n i v e r s i t a s ~ S e b e l a s ~ M a r e t ~ S u r a k a r t a, ~ I n d o n e s i a ~}$ \\ ${ }^{1}$ mastikno@gmail.com; ${ }^{2}$ retnowinarni@staff.uns.ac.id; ${ }^{3}$ yitsuyitno52@gmail.com; \\ ${ }^{4}$ nugraheniekowardani_99@yahoo.co.id

\section{Article info} \\ A B S T R A C T
}

Article history:

Received: 01-10-2020

Revised : 15-11-2020

Accepted: 10-12-2020

Keywords:

high schools in Brebes learning to write poetry multiculturalism

This study aims to describe learning to write poetry in high schools in Brebes Regency. (1) the importance of developing learning to write poetry for high school students that is attractive and fun, (2) the importance of the dimensions of the knowledge construction process in the learning process, (3) there is no model deemed appropriate for learning to write poetry, (4) the importance of the media used in learning to write poetry for high school students, and (5) the importance of introducing students to multiculturalism in learning to write poetry. Things that are needed by teachers and students in learning to write poetry include: (1) easy-to-use media, (2) an interesting and fun learning atmosphere, (3) can develop students' talents and interests, (4) can increase social feelings between friends, and (5) can train courage and self-confidence.

Penelitian ini bertujuan untuk mendeskripsikan pembelajaran menulis puisi di SMA se-Kabupaten Brebes. (1) pentingnya pengembangan pembelajaran menulis puisi siswa SMA yang menarik dan menyenangkan, (2) pentingnya dimensi The knowledge construction process dalam proses pembelajaran, (3) belum adanya model yang dianggap tepat untuk pembelajaran menulis puisi, (4) pentingnya media yang digunakan dalam pembelajaran menulis puisi siswa SMA, dan (5) pentingnya mengenalkan kepada siswa tentang multikultural dalam pembelajaran menulis puisi. Hal yang diperlukan guru dan siswa pada pembelajaran menulis puisi, meliputi: (1) media yang mudah digunakan, (2) suasana pembelajaran yang menarik dan menyenangkan, (3) dapat mengembangkan bakat dan minat siswa, (4) dapat meningkatkan rasa sosial antarteman, dan (5) dapat melatih keberanian dan percaya diri.

Copyright $\odot 2020$ Institut Agama Islam Negeri Syekh Nurjati Cirebon. All rights reserved.

\section{PENDAHULUAN}

Pembelajaran merupakan inti dari proses pendidikan secara keseluruhan. Kualitas belajar-mengajar ditentukan oleh semua komponen yang terlibat di dalamnya terutama pelaku pada proses belajar, yaitu guru dan siswa. Hal ini dapat memotivasi guru untuk meningkatkan peranan dan kompetensinya karena proses dan hasil belajar siswa sebagian besar ditentukan oleh guru sebagai fasilitator. Guru harus mampu merencanakan pembelajaran dengan baik khususnya menyusun rencana pembelajaran. Guru harus mampu melaksanakan pembelajaran dengan kreatif dan inovatif sehingga tumbuh kreatif dan daya imajinatif yang tinggi pada para siswa yang sedang belajar. Selain itu, guru harus mampu memberi penilaian yang objektif kepada para siswa. 
Keberhasilan proses belajar membutuhkan keterlibatan beberapa unsur pengajaran, yaitu: guru, siswa, materi pelajaran, media pengajaran, tujuan, metode pengajaran, dan sarana pendukung lainnya. Perangkat pengajaran tersebut tidak dapat berdiri sendiri. Setiap unsur memiliki peran masing-masing dalam menghasilkan proses belajar. Dengan demikian, keberhasilan itu menuntut integritas setiap unsur. Guru merupakan unsur utama dalam pembelajaran karena roh di kelas dalam pembelajaran adalah guru. Oleh karena itu, sudah selayaknya guru harus memiliki empat kompetensi, yakni: pedagogik, profesional, kepribadian, dan sosial.

Peran guru dalam kegiatan belajar-mengajar tidak sekadar menyampaikan ilmu kepada peserta didik, tetapi juga memberi bimbingan, arahan, motivasi, serta membentuk karakter dengan baik. Dominasi guru dalam pembelajaran, khususnya menulis puisi, juga menyebabkan siswa lebih banyak tidak memiliki peran dan terlibat secara pasif. Siswa banyak menunggu sajian dari guru daripada mencari dan menemukan sendiri pengetahuan, keterampilan, serta sikap yang dibutuhkan. Kondisi semacam ini kurang mendukung peningkatan kualitas pendidikan, khususnya kualitas pengajaran bahasa Indonesia dalam pembelajaran menulis puisi di sekolah. Sangat tidak tepat jika para siswa tidak dilibatkan dalam pembelajaran karena target utama pembelajaran bahasa Indonesia adalah empat keterampilan berbahasa, yakni: menyimak, berbicara, membaca, dan menulis.

Puisi memiliki fungsi utile dan dulce, yaitu bermanfaat dan nikmati atau menghibur. Puisi bermanfaat karena proses penciptaannya melalui kontemplasi tentang hidup dan kehidupan sehingga ada sesuatu yang ingin disampaikan oleh penyair melalui puisinya dan sesuatu itu berguna atau bermanfaat bagi pembacanya. Selain bermanfaat, puisi juga menghibur karena bersifat estetis. Estetika puisi dapat dinikmati, antara lain melalui diksi, pengimajian, kata-kata konkret, majas, versifikasi, dan tipografi.

Sampai saat ini, pembelajaran menulis puisi dilakukan di sekolah-sekolah dan di sejumlah perguruan tinggi. Hal ini terjadi karena pembelajaran menulis puisi diakui memiliki fungsi dan manfaat bagi kehidupan manusia. Pembelajaran menulis puisi berfungsi melatih keterampilan berbahasa siswa, yaitu melatih berimajinasi agar mampu menuangkan ide sehingga keterampilan menulis menjadi lebih berkualitas. Pembelajaran menulis puisi di SMA bertujuan meningkatkan kemampuan siswa berlatih mempertajam penalaran, daya khayal, kepekaan terhadap masyarakat, budaya, dan lingkungan hidup. Materi menulis puisi terdapat pada pembelajaran yang diajarkan di kelas $\mathrm{X}$, yakni mengenal pembelajaran menulis puisi.

Pembelajaran menulis puisi selama ini cenderung berkaitan dengan kondisi alam dan percintaan. Selain itu, guru dalam menyampaikan materi pelajaran menulis puisi kurang memperhatikan latar belakang peserta didik yang beragam, misalnya: status ekonomi, suku, agama, dan kompetensi dalam menulis puisi. Siswa tidak diarahkan menciptakan atau menulis puisi multikultural. Siswa cenderung menulis puisi-puisi yang bertema, misal: pendidikan, pahlawan, percintaan, dan lingkungan. Hal ini berakibat pada pengabaian tentang pluralisme maupun keberagaman budaya. Keberagaman budaya atau multikultural yang ada di kelas sebenarnya merupakan potret atau gambaran multikultural.

Pembelajaran menulis puisi merupakan aspek keterampilan yang mengarahkan siswa untuk praktik menulis kreatif. Puisi merupakan gambaran berbagai peristiwa sosial, seperti: penipuan, penghinaan, pengkhianatan, 
perampokan, pencurian, perampasan, dan penodongan. Selain itu, puisi juga menggambarkan berbagai peristiwa menggembirakan, seperti: pertolongan, persetujuan, persahabatan, dan percintaan. Berbagai peristiwa sosial tersebut merupakan fenomena multikultural yang berkelindan dalam lingkungan siswa. Untuk itu, pembelajaran menulis puisi perlu mengangkat keberagaman budaya atau multikultural di lingkungan siswa. Hal ini dapat menjadi salah satu pengembangan dalam pembelajaran menulis puisi.

Pengembangan pembelajaran tidak begitu saja dapat dilakukan guru. Aktivitas yang dilakukan pengajar mulai saat masuk kelas hingga mengakhiri pembelajaran, tidak terlepas dari aktivitas penggunaan model pembelajaran (Andayani, 2014). Guru memiliki peran penting, yakni sebagai manager pembelajaran (Rohmadi, 2012). Oleh karena itu, pengembangan pembelajaran bergantung pada kemampuan guru dalam menyelenggarakan pembelajaran di kelas (Mulyaningsih, 2016). Salah satu pembelajaran yang perlu dikembangkan adalah menulis puisi. Puisi memberi pengetahuan terkait manusia sebagai makhluk sosial, yang terlibat dalam masalah sosial. Secara imajinatif, puisi dapat menafsirkan situasi dasar manusia, yang dapat berupa penderitaan atas ketidakadilan, perjuangan untuk kekuasaan, konflik manusia dengan sesama manusia, pemberontakannya terhadap hukum Tuhan atau hukum manusia sendiri. Manusia sebagai makhluk sosial dan makluk budaya pada dasarnya dipengaruhi oleh nilai-nilai kemanusiaan. Nilai-nilai tersebut baik berupa etika yang erat hubungannya dengan moralitas maupun estetika yang berhubungan dengan rasa keindahan (Ismawati, 2013).

Observasi pembelajaran di lima SMA negeri se-kabupaten Brebes menunjukkan bahwa kualitas pembelajaran menulis puisi masih bersifat tematik, kognitif (Dressman \& Faust, 2014), dan perlu ditingkatkan kualitasnya. Pelaksanaan pembelajaran menulis puisi masih didominasi guru. Guru lebih banyak menggunakan metode ceramah dan berteori (Mustakim, 2010), sedangkan kondisi siswa diketahui kurang aktif dan kurang berminat belajar menulis puisi. Siswa beranggapan bahwa menulis puisi tidak bermanfaat untuk mempersiapkan masa depannya sehingga kurang aktif mengeluarkan ide-idenya dalam praktik menulis puisi. Selain itu, situasi dan kondisi siswa dalam mengikuti pembelajaran menulis puisi kurang kondusif. Siswa yang duduk di belakang cenderung kurang konsentrasi dan tidak menyimak penjelasan guru karena diawali tidak senang praktik menulis puisi.

Berdasarkan kondisi di lapangan maka perlu disusun model pembelajaran menulis puisi dengan berbasis multikultural agar dapat membuka wawasan siswa tentang keadaan sekitar yang sangat beragam (Asrori, 2012; Tonbuloglu, Aslan, \& Aydin, 2016). Dengan pendidikan berbasis multikultural, siswa diharapkan dapat melakukan survei di lingkungan masing-masing (Zulaikha, 2009; Alghamdi, 2017). Siswa diharap dapat memahami kondisi kultur yang sangat beragam di sekitarnya (Aliismail, 2016) sehingga dapat memunculkan banyak ide dalam menulis puisi. Selanjutnya, pembelajaran dilakukan dengan metode sinektik agar siswa bisa berdiskusi dengan teman-temannya untuk menggali potensi kultural yang ada di lingkungan masing-masing (Patil, 2012; Irmawati, 2014). Pembelajaran puisi berbasis pendidikan multikultural ini dapat membebaskan alam bawah sadar individu dan kolektif sambil mengungkapkan metafora budaya yang mendasari pemikiran divergen (Amat, 2012). Mengajar dengan metode synectics tidak hanya akan meningkatkan kreativitas (Momin \& Geetha, 2019; 
Suratno dkk, 2019) tentang kelancaran, orisinalitas, flexibilitas dan elaborasi, tetapi juga akan meningkatkan perbedaan individu (Tajari, Tayebeh, \& Tajari, 2011).

Oleh karena itu, pembelajaran menulis puisi perlu dikembangkan agar siswa memiliki kesadaran yang tinggi dalam menentukan pilihan-pilihan yang paling tepat sebagai tuntunan hidup di masa depan. Salah satunya dengan mengintegrasikan pada mata pelajaran bahasa Indonesia. Dengan demikian, pembelajaran bahasa Indonesia merupakan media yang dapat menjembatani melalui keterampilan menulis kreatif di SMA perlu dilakukan. Hal ini sesuai dengan tujuan pembelajaran menulis puisi yaitu untuk meningkatkan kemampuan siswa dalam mengapresiasikan karya sastra, perlu ditemukan fenomena multibudaya.

\section{METODE}

Penelitian ini menggunakan bentuk deskriptif kualitatif naturalistik, yaitu penelitian yang datanya berupa kata-kata, gambar, dan bukan angka-angka (Moleong, 2010). Data dikumpulkan sebanyak-banyaknya yang terkait dengan: (1) perencanaan pembelajaran menulis puisi di lima SMA kabupaten Brebes, (2) pelaksanaan pembelajaran menulis puisi di lima SMA kabupaten Brebes, dan (3) penilaian pembelajaran menulis puisi di SMA kabupaten Brebes.

Teknik pengumpulan data menggunakan observasi, wawancara, dan analisis dokumen. Observasi dilaksanakan secara terencana dan terkontrol dengan mengadakan pengamatan secara langsung terhadap proses pembelajaran menulis puisi di kelas. Wawancara dilaksanakan secara struktur kepada guru dan siswa mengenai pelaksanaan pembelajaran menulis puisi. Observasi dan wawancara dilakukan terhadap guru sebanyak 5 orang guru dan siswa sebanyak 10 siswa. Observasi dan wawancara dilakukan dari April sampai Agustus 2015. Untuk menjamin ketepatan instrumen penelitian, maka dilakukan triangulasi. Di antara beberapa model triangulasi yang digunakan adalah triangulasi data atau triangulasi sumber (Sutopo, 2002). Prosedur yang dilakukan untuk menjamin ketepatan instrumen yaitu dengan menyusun kisi-kisi, konsultasi dengan penilaian pakar, dan melakukan analisis validitas dan reliabilitas. Adapun instrumen penelitian disusun berdasarkan kisi-kisi pada tabel 1 .

Data yang terkumpul dianalisis menggunakan prinsip kerja model analisis interaktif yang terdiri atas tiga alur kegiatan, yaitu reduksi data, penyajian data, dan penarikan simpulan atau verifikasi (Sugiyono, 2013). Reduksi data dilakukan dengan menyederhanakan data yang diperoleh dari catatan lapangan. Tujuannya untuk mempertegas, memperpendek, dan membuang hal-hal yang penting serta mengatur data demikian rupa sehingga simpulan penelitian dapat dilakukan. Data yang telah direduksi, disajikan. Tahap berikutnya pengambilan simpulan.

Penelitian dilakukan di lima sekolah menengah atas kabupaten Brebes, yaitu SMA Negeri 3 Brebes, SMA Negeri Wanasari, SMA Negeri Larangan, SMA Negeri Tanjung, SMA Negeri Bulakamba. Penelitian dilaksanakan pada semester ganjil 2015-2016. Penelitian dilakukan dengan langkah-langkah sebagai berikut. Tahap pendahuluan atau eksplorasi, meliputi: 1) pengumpulan data tahap eksplorasi melalui wawancara dan observasi, 2) analisis data tahap eksplorasi, dan 3) penyusunan laporan tahap eksplorasi. 
Tabel 1. Kisi-Kisi Instrumen Penelitian

\begin{tabular}{|c|c|c|}
\hline DIMENSI & INDIKATOR & $\begin{array}{l}\text { NOMOR } \\
\text { SOAL }\end{array}$ \\
\hline \multirow{4}{*}{$\begin{array}{l}\text { Pembelajaran } \\
\text { menulis puisi }\end{array}$} & 1. Menjelaskan teori dasar menulis puisi & 5 \\
\hline & $\begin{array}{l}\text { 2. Menjelaskan suasana proses belajar-mengajar } \\
\text { menulis puisi }\end{array}$ & 4,6 \\
\hline & $\begin{array}{l}\text { 3. Menentukan perbedaan puisi umum dengan puisi } \\
\text { berbasis pendidikan multikultural, serta contoh } \\
\text { puisi }\end{array}$ & 15,17 \\
\hline & $\begin{array}{l}\text { 4. Menjelaskan tugas atau pekerjaan rumah akhir } \\
\text { pembelajaran }\end{array}$ & 20 \\
\hline \multirow{3}{*}{$\begin{array}{l}\text { Menulis puisi } \\
\text { multikultural }\end{array}$} & 1. Menentukan menulis puisi multikultural & 1 \\
\hline & $\begin{array}{l}\text { 2. Menjelaskan kendala praktik menulis puisi } \\
\text { multikultural }\end{array}$ & 2 \\
\hline & $\begin{array}{l}\text { 3. Menentukan sikap dalam praktek menulis puisi } \\
\text { multikultural }\end{array}$ & $\begin{array}{c}10,12 \\
14,18,19\end{array}$ \\
\hline \multirow[t]{2}{*}{$\begin{array}{l}\text { Menulis puisi } \\
\text { monokultural }\end{array}$} & $\begin{array}{l}\text { 1. Menentukan menulis puisi tema Ketuhanan, } \\
\text { kejujuran }\end{array}$ & 7,8 \\
\hline & 2. Menentukan puisi hasil karya sendiri & 9 \\
\hline Membaca puisi & 1. Mempraktikan membaca puisi karya teman & \\
\hline karya teman & & 11,13 \\
\hline $\begin{array}{l}\text { Model } \\
\text { pembelajaran } \\
\text { sinektik }\end{array}$ & 1. Mengenalkan model pembelajaran sinektik & 3 \\
\hline
\end{tabular}

\section{HASIL DAN PEMBAHASAN}

Dari studi pendahuluan ditemukan adanya dua pokok permasalahan, yaitu: (1) permasalahan dan kebutuhan guru dalam proses pembelajaran menulis puisi, dan perbaikan pembelajaran proses pembelajaran menulis puisi dan (2) permasalahan dan kebutuhan siswa dalam proses pembelajaran menulis puisi. Eksplorasi dilakukan untuk mengumpulkan informasi dan mendapatkan masukan melalui observasi dan pengamatan langsung, serta wawancara kepada guru dan siswa, di lima SMA negeri se-kabupaten Brebes. Hasil observasi, wawancara, dan dokumen-dokumen tentang model-model pembelajaran menulis puisi sebagai berikut.

\section{Analisis Kebutuhan Guru}

Permasalahan dan kebutuhan guru dan siswa dalam pembelajaran menulis puisi di sekolah menengah atas melalui observasi atau pengamatan, dan wawancara. Berdasarkan hasil observasi dan wawancara dengan guru maupun siswa, banyak temuan masalah yang dihadapi dalam pembelajaran menulis puisi. Setelah dilakukan wawancara dengan guru pengampu mata pelajaran bahasa Indonesia dan observasi administrasi guru di kelas antara lain berkaitan tentang (1) penyusunan rencana pembelajaran menulis puisi; (2) penerapan prosedur pembelajaran; (3) penerapan sumber dan media pembelajaran.

Pertama, masalah dan kebutuhan guru dalam penyusunan Rencana Pelaksanaan Pembelajaran (RPP) menulis puisi di SMA. Setiap awal semester, guru menyusun RPP. Berdasarkan wawancara, guru selalu membuat RPP sesuai dengan kondisi siswa, dan selalu memperbaiki di semester berikutnya. Informan juga mengatakan hampir sama bahwa dalam menyusun rencana pelaksanaan 
pembelajaran menulis puisi sangat variatif dan banyak mengalami kesulitan. Kesulitan guru dalam menyusun RPP, yakni masih awal penerapan kurikulum 2013 di kabupaten Brebes sehingga masih sering muncul keraguan. Hal ini karena belum semua guru pengampu mata pelajaran bahasa Indonesia memahami secara utuh penerapan kurikulum 2013 dari perencanaan, pelaksanaan pembelajaran, dan penilaian pembelajaran. Selain itu, kurikulum 2013 selalu ada penyempurnaanpenyempurnaan.

Hal tersebut diungkapkan oleh guru Rtn dalam catatan hasil wawancara yakni guru atau informan tersebut mengalami kesulitan menyusun RPP karena sangat berbeda penyusunan rencana pelaksanaan pembelajaran kurikulum KTSP, informan menjelaskan masih kebingungan memahami KI 1, KI 2, KI 3,dan KI 4 apalagi menuliskan langkah-langkah kegiatan belajar-mengajar. Senada yang diungkapkan oleh guru Sc, dijelaskan bahwa penyusunan rencana pelaksanaan pembelajaran kurikulum 2013 lebih sulit dibandingkan dengan penyusunan RPP KTSP. Hal ini dijelaskan oleh informan karena sulit menghubungkan dan memilih KI. Selain itu, penjabaran kompetensi dasar harus ditulis secara lengkap.

Masalah yang diungkapkan oleh informan Ela, yaitu berkaitan dengan penyusunan RPP tentang menulis puisi sangat sulit memilah-milah dari KI, Kompetensi Dasar, Indikator, apalagi menjabarkan kegiatan belajar-mengajar. Penyampaian materi menulis puisi kurang mendapat perhatian. Dikatakan oleh informan guru (Tk) "Bahwa saya sendiri tidak suka materi pembelajaran sastra terutama menulis puisi”. Informan juga menjelaskan bahwa jika praktik menulis puisi mengalami kesulitan dalam memilih kata-kata yang indah. Selain itu, guru sulit menemukan ide. Oleh karena itu, siswa diminta untuk mengeksplor dengan cara keluar kelas untuk mendapatkan imajinasi.

Berdasarkan hasil observasi pembelajaran di kelas, informan kurang siap menyampaikan materi pembelajaran menulis puisi. Hal ini ditunjukkan oleh Ela. Pelaksanaan pembelajaran masih bersifat konvensional. Artinya, guru masih mendominasi pembelajaran. Selain itu, pembelajaran menulis puisi didominasi dengan membaca puisi yang ada pada buku paket. Padahal materi pokok adalah menulis puisi. Hasil observasi di sekolah lain ditemukan bahwa informan tampak gugup dalam memulai pembelajaran menulis puisi. Guru tampak repot memulai pembelajaran. Guru tidak runtut dalam melaksanaan pembelajaran. Berdasarkan pelaksanaan pembelajaran tersebut dapat disimpulkan bahwa guru kurang siap menyampaikan materi pembelajaran. Hal ini karena guru tersebut tidak menyusun RPP menulis puisi sehingga dalam pelaksanaan pembelajaran tampak tidak siap.

Informan juga mengatakan bahwa dalam menyusun RPP merasa sudah terarah dan sesuai kurikulum 2013, tetapi kadang masih merasa kurang percaya diri. Tak jarang informan selalu berusaha untuk memperbaiki RPP dengan baik. Hak ini dilakukan dengan bertanya kepada sesama guru Bahasa Indonesia di sekolah yang sama juga ketika ada pertemuan musyawarah guru mata pelajaran (MGMP).

Kedua, masalah dan kebutuhan guru dalam penerapan prosedur pembelajaran menulis puisi siswa SMA. Masalah juga dihadapi guru dalam proses pembelajaran, yaitu berkaitan dengan penerapan prosedur pembelajaran menulis puisi. Hasil observasi di kelas X SMA Negeri 3 Brebes, SMA Negeri 1 Bulakamba, SMA Negeri Tanjung, SMA Negeri Larangan, dan SMA Negeri 1 Wanasari dapat diidentifikasi permasalahan yang hampir sama, yaitu tentang penerapan prosedur pembelajaran. Dominan guru dalam menerapkan 
pembelajaran menulis puisi dengan cara siswa diajak membaca puisi yang ada pada buku paket. Siswa kurang diberi kesempatan untuk berkreasi dan eksploratif. Praktik menulis puisi cenderung bertema yang sama.

Temuan berdasarkan pelaksanaan observasi di kelas, guru (Rt) dalam pelaksanaan pembelajaran menulis puisi memulai dengan penjelasan teori tentang puisi. Guru melakukan tanya jawab tentang materi yang akan disampaikan. Guru memberi motivasi kepada siswa bahwa menulis dapat melatih kreativitas juga menambah percaya diri. Guru memberi contoh-contoh karya puisi. Permasalahan lain berkaitan interaksi guru dan siswa. Guru (Ela) memulai dengan langsung membacakan puisi di kelas sehingga para siswa kaget penuh tanda tanya materi apa pada pagi ini. Setelah guru selesai membacakan sebuah puisi guru menjelaskan tentang teori cara menulis puisi yang baik. Hal ini menunjukkan bahwa guru kurang memperhatikan pendahuluan pembelajaran.

Dari temuan-temuan observasi pada saat pembelajaran berlangsung, para guru masih mendominasi kelas dalam pembelajaran menulis puisi. Siswa kurang diberi kesempatan untuk mengeksploras dan berkreasi. Selain itu, walaupun materinya tentang menulis puisi, tetapi masih dominan penjelasan dan contoh pembacaan puisi yang terdapat pada buku teks. Guru mengakhiri pembelajaran dengan memberi pekerjaan rumah tentang cara menulis puisi. Dengan demikian pada saat dilakukan observasi pembelajaran, guru cenderung membahas teori menulis puisi. Guru selalu memberi tugas menulis puisi secara perorangan setelah materi menulis puisi sudah selesai.

Ketiga, permasalahan dan kebutuhan guru dalam penentuan media dan sumber pembelajaran menulis puisi. Media dan sumber pembelajaran sangat membantu dalam proses pembelajaran karena akan membantu para siswa lebih cepat memahami materi pembelajaran. Observasi dilakukan di beberapa sekolah dan diketahui bahwa media pembelajaran dianggap kurang penting. Hal ini diketahui karena guru tidak memanfaatkan media visual, media audio, apalagi media audio visual. Setelah dilakukan wawancara terhadap beberapa informan, guru merasa repot dan susah jika dalam mengajar harus mempersiapkan banyak hal termasuk menyiapkan media pembelajaran. Temuan lain berupa masih terdapat siswa yang kurang fokus mengikuti pembelajaran menulis puisi sehingga kelas agak gaduh. Hal ini ditemukan bahwa tidak adanya media sehingga membuat konsentrasi siswa kurang fokus dan kurang menarik. Informan (Tk) ketika menyampaikan materi menulis puisi tidak pernah menggunakan media, tetapi siswa dikenalkan alam atau lingkungan sebagai media langsung untuk mendapatkan imajinasi penulisan puisi. Sumber pembelajaran ditemukan masih monoton, yaitu hanya berkutat dari sumber buku pelajaran atau buku paket. Sebagian besar guru tidak memberi kesempatan kepada siswa bahwasannya sumber pelajaran yang berkaitan dengan menulis puisi sangat banyak termasuk alam semesta, majalah, dan jurnal.

Keempat, masalah materi pembelajaran menulis puisi. berdasarkan hasil wawancara, guru kurang memahami pembelajaran berbasis multikultural, apalagi pembelajaran menulis puisi berbasis multikultural. Informan (Rt), (Tk), dan (Sc) sudah tahu tentang multikultural, tetapi belum menerapkan dalam pembelajaran sastra apalagi menulis puisi. Informan hanya berfokus pada tematik sesuai amanat kurikulum 2013. Informan (St) menyampaikan bahwa pembelajaran berbasis multikultural sama sekali belum pernah diterapkan dalam pembelajaran, apalagi menulis puisi. Jadi, hal tersebut masih terasa asing. Pemahaman informan terkait 
multikultural lebih terkait dengan budaya, misal budaya-budaya Jawa seperti tujuh bulanan seorang wanita yang hamil. Siswa diminta menulis puisi berdasarkan tujuh bulanan itu. Dengan demikian, informan menjelaskan bahwa pembelajaran menulis puisi masih tematik saja.

Kelima, masalah dan kebutuhan guru berkaitan dengan penerapan model. Berdasarkan hasil wawancara, pembelajaran sudah menerapkan model-model pembelajaran. Namun demikian, belum secara lengkap menerapkan sintak secara runtut sesuai model yang dipergunakan. Beberapa informan menjelaskan hampir sama, yaitu guru sudah mempraktikan model pembelajaran meskipun tidak taat pada sintak. Selain itu, guru tidak mengerti model yang diterapkan kepada siswa. Informan berpikir yang penting anak aktif dan bisa menulis puisi dengan mudah dan berkualitas. Secara umum, informan mengatakan bahwa belum pernah menerapkan model sinektik dan baru mendengar nama model sinektik ini. Informan (Sc) sudah sering menerapkan berbagai model pembelajaran, tetapi model sinektik sama sekali tidak paham. Pernyataan yang sama disampaikan oleh informan (Tk) yang menyatakan bahwa siswa sering diajak keluar kelas untuk melihat pemandangan. Hal ini untuk mendapatkan imajinasi sehingga siswa dengan mudah praktik menulis puisi. Namun, informan tidak paham nama model pembelajaran yang digunakan. Berkaitan model sinektik informan baru mendengar. Secara jujur, informan belum pernah menerapkan model sinektik dalam pembelajaran menulis puisi.

Pembelajaran puisi hendaknya bukan studi orisinal yang menelusuri sejarah wacana tentang pengajaran puisi (Triyanto, Sumarwati, \& Saddhono, 2018). Koda atau analisis kesimpulan yang memunculkan pertanyaan tentang fungsi sejarah sebagai trope (Mulatsih, 2018), serta (3) peran sejarah pendidikan puisi di masa kini. Dari penelitian tersebut menggambarkan bahwa pembelajaran puisi tidak hanya menjadi problem di Indonesia, tetapi juga di negara lain.

\section{Analisis Kebutuhan Siswa}

Pertama, masalah dan kebutuhan siswa SMA dalam pembelajaran menulis puisi. Berdasarkan hasil wawancara dan observasi pada proses pembelajaran di kelas, terdapat berbagai masalah terkiat kesulitan menemukan ide dan menulis puisi. Mayoritas siswa mengatakan bahwa pembelajaran menulis puisi menyenangkan, tetapi siswa sulit menemukan ide atau gagasan. Siswa merasa kesulitan memilih kata-kata yang indah, apalagi memasukkan majas-majas. Berdasarkan apa yang disampaikan siswa membuktikan bahwa pembelajaran menulis puisi dirasakan menyenangkan, tetapi sulit dan susah. Dani mengatakan bahwa pembelajaran sastra memang menyenangkan, tetapi "belajar menulis puisi saya tidak begitu suka karena saya tidak dapat menuangkan ide atau gagasan, serta kesulitan memilih kata-kata yang indah". Jono juga belajar menulis puisi sejak di SD dan SMP, tetapi masih kesulitan dalam menuangkan ide atau gagasan ketika di SMA. Jono juga merasa kesulitan memilih kata-kata yang tepat untuk puisi. Diungkapkan pula oleh Siti bahwa belajar menulis puisi sangat menyenangkan, tetapi untuk menuangkan ide atau gagasan masih sulit. Dari beberapa ungkapan para siswa dari sekolah yang berbeda membuktikan bahwa belajar menulis puisi itu menyenangkan, tetapi sulit untuk diterapkan. Menulis puisi sulit bagi siswa yang tidak berbakat.

Temuan selanjutnya adalah permasalahan minat dan bakat. Keberhasilan siswa dalam praktik menulis puisi dipengaruhi minat dan bakat. Hal ini dibuktikan dari beberapa ungkapan siswa. 
"Setiap ada materi sastra khususnya menulis puisi saya tidak semangat mengikuti pembelajaran di kelas karena diri saya tidak memiliki bakat menulis puisi, susah menuangkan ide atau gagasan, apalagi memilih kata-kata yang tepat dan indah sehingga setiap ada pembelajaran menulis puisi hasilnya kurang bagus". (Mira)

"Bakat saya adalah musik sehingga rasanya tidak tertarik mengikuti pembelajaran menulis puisi". (Dani)

"Sebenarnya saya suka menulis puisi tetapi saya tidak memiliki bakat menulis puisi". (Ani)

Pembelajaran menulis puisi cenderung tidak diminati oleh siswa. Berkaitan dengan hal tersebut, guru diharapkan mampu membantu siswa. Berikut ini pernyataan siswa terkait hal tersebut.

"Setiap pembelajaran menulis puisi siswa merasa tidak semangat karena dianggap hanya membuang waktu saja dan tidak ada manfaatnya". (Watik)

"Belajar menulis puisi percuma hanya membuang waktu belaka". (Hari)

"Belajar itu penting baik pengetahuan, keterampilan, dan sikap, namun pengetahuan yang bisa untuk masa depan bekal kehidupan sedangkan belajar menulis puisi tidak bisa menjamin sukses dalam kehidupan". (Kiswanto)

Berdasarkan data tersebut dapat disimpulkan bahwa permasalahan yang dialami peserta didik dalam menulis antara lain karena kurang kreatif dalam menggunakan cara atau metode pembelajaran atau pendekatan pembelajaran (Khan, 2011). Selama ini, peserta didik hanya mendasarkan pada yang dilihat maupun yang dibaca kemudian secara ulang dituangkan dalam bentuk tulisan. Salah satu yang dapat dilakukan oleh guru untuk meningkatkan keterampilan siswa dalam menulis puisi adalah melalui permainan. Permainan ini menyasar pada jenis puisi yang paling tidak disukai oleh siswa. Permainan ini juga dapat diakses sendiri karena dilengkapi dengan jawaban di kartu jawaban. Pembelajaran dengan permainan papan puisi ini dapat memberikan variasi yang sangat dibutuhkan (Vijayarajoo, et.al., (2019).

\section{SIMPULAN}

Berdasarkan analisis dapat disimpulkan bahwa terdapat permasalahan dalam pembelajaran menulis puisi siswa SMA. Adapun permasalahan tersebut, meliputi: (1) pentingnya pengembangan pembelajaran menulis puisi siswa SMA yang menarik dan menyenangkan, (2) pentingnya dimensi The knowledge construction process dalam proses pembelajaran, (3) belum adanya model yang dianggap tepat untuk pembelajaran menulis puisi, (4) pentingnya media yang digunakan dalam pembelajaran menulis puisi siswa SMA, dan (5) pentingnya mengenalkan kepada siswa tentang multikultural dalam pembelajaran menulis puisi. Hal yang diperlukan guru dan siswa pada pembelajaran menulis puisi, meliputi: (1) media yang mudah digunakan, (2) suasana pembelajaran yang menarik dan menyenangkan, (3) dapat mengembangkan bakat dan minat siswa, (4) dapat meningkatkan rasa sosial antarteman, dan (5) dapat melatih keberanian dan percaya diri. 
Berdasarkan hal tersebut, perlu dikembangkan pembelajaran menulis puisi berbasis pendidikan multikultural dengan model sinektik siswa SMA. Hasil penelitian ini menawarkan kebaruan dalam pembelajaran, khususnya pembelajaran menulis puisi. Pembelajaran puisi dengan berbasis pendidikan multikultural bertujuan agar siswa memiliki banyak wawasan tentang lingkungannya sehingga memudahkan mencari ide atau gagasan dalam menulis puisi. Sementara itu, model pembelajaran sinektik yang diterapkan dalam pembelajaran menulis puisi diharapkan dapat menumbuhkan kerja sama dan menambah wawasan dari teman-temannya dengan lebih cepat dan lebih banyak. Dengan demikian, diharapkan siswa tidak bingung mencari ide gagasan untuk tema puisi yang akan ditulisnya.

\section{DAFTAR PUSTAKA}

Alghamdi, Y. (2017). Multicultural Education in the US: Current Issues and Suggestions for Practical Implementations. International Journal of Education, 9(2), 44 - 52.

Aliismail, H. A. (2016). Multicultural Education: Teachers' Perceptions and Preparation. Journal of Education and Practice, 7(11), 139 - 146.

Andayani. (2014). Pendekatan Saintifik dan Metodologi Pembelajaran Bahasa Indonesia. Surakarta: Yuma Pustaka.

Amat, A. A. (2012). The Role of poetry in the Transmission of Divergent Thinking. International Journal of Humanities and Social Science, 2(21), 28 $-34$

Asrori, M. (2012). Psikologi Pembelajaran. Bandung: Wacana Prima.

Dressman \& Faust, M. (2014). On the Teaching of Poetry in English Journal, 1912-2005: Does History Matter? Journal of Literacy Research, 46(1), 3967.

Irmawati, N. D. (2014). Understanding how to Analyze Poetry and its Implication to Language Teaching International Journal on Studies in English Language and Literature, 2(11), $35-45$.

Ismawati, E. (2013). Pengajaran Sastra. Yogyakarta: Ombak.

Khan, H. I. (2011). Testing Creative Writing in Pakistan: Tensions and Potential in Classroom Practice. International Journal of Humanites and Social Science, 1(15), $111-119$.

Moleong, L J. (2010). Metode Penelitian Kualitatif. Edisi Revisi. Bandung: Remaja Rosdakarya.

Momin, P. I. \& Geetha. (2019). Impact of Synectics Model of Teaching on Achievement in Social Science Creativity and Achievement Motivation Among 9th Standard Secondary School Students of Vijayapura City. Karnataka State Womens University

Mulatsih, M. V. E. (2018). Learning Poetry as a Strategy to Develop Students` Teaching Skills. International Journal of Indonesian Education and Teaching, 2(2), $120-128$.

Mulyaningsih, I., Suwandi, S., Setiawan, B., \& Rohmadi, M. (2016). Model Pembelajaran Menulis Ilmiah Berbasis PARMI (Produksi, Atemsi, Retensi, Motivasi, dan Inovasi) dan Penerapannya. Confident: Cirebon.

Mustakim. (2010). Membina Kemampuan Berbahasa. Jakarta: PT Gramedia. Pustaka Utama. 


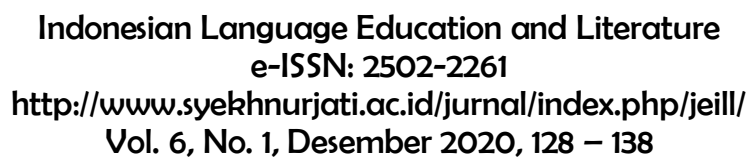

Patil, R. (2012). Effecitiveness of Synectics Model. Indian Streams Research Journal, 1(V), $1-4$.

Rohmadi, M. (2012). Menjadi Guru Profesional \& Berkarakter. Surakarta: Yuma Pustaka.

Sugiyono. (2013). Metode Penelitian Pendidikan. Bandung: Alfabeta.

Suratno, Komaria, N., Yushardi, Dafik, \& Wicaksono, I. (2019). The Effect of Using Synectics Model on Creative Thinking and Metacognition Skills of Junior High School Students. International Journal of Instruction, 12(3), $133-150$.

Sutopo. (2002). Metodologi Penelitian Kualitatif. Surakarta: UNS Press.

Tajari, Tayebeh, \& Tajari, F. (2011). Comparison of effectiveness of synectics teaching methods with lecture about educational Progress and creativity in social studies lesson in Iran at 2010. Social and Behavioral Sciences, 28, $451-454$

Tonbuloglu, B., Aslan, D., Aydin, H. (2016). Teachers' Awareness of Multicultural Education and Diversity in School Settings. Eurasian Journal of Educational Research, 64, 1-28.

Triyanto, Sumarwati, \& Saddhono, K. (2018). Improving Students` Interest in Poetry Writing Learning by Using Technique. Lingua Didaktika, 12(1), 34 44.

Vijayarajoo, A. R., Yatim, A. I. A., Singh, K. K. M., \& Jani, R. M. (2019). Poetricks: A Game to Engage Malaysian Secondary School ESL Learners in Understanding PoetrySocial and Management Research Journal, 16(1), 55 -72 .

Zulaikha, I. (2009). Pengembangan Model Pembelajaran Inkuiri Sosial Bagi Peningkatan Kemampuan Menulis Kreatif dalam Konteks Multikultural Siswa SMP. Disertasi, Sekolah Pasca Sarjana. UPI Bandung. 